\title{
Hubungan Pola Penggunaan OAINS dengan Gejala Klinis Gastropati pada Pasien Reumatik
}

\section{Relationship of NSAID Utilization Pattern With Gastropathy Symptoms in Rheumatic Patient}

\author{
Yoga Waranugraha ${ }^{1}$, BP Putra Suryana ${ }^{2}$, Bogi Pratomo ${ }^{3}$ \\ ${ }^{1}$ Program Studi Pendidikan Dokter Fakultas Kedokteran Universitas Brawijaya Malang \\ ${ }^{2}$ Divisi Reumatologi Bagian IImu Penyakit Dalam Rumah Sakit Umum Dr. Saiful Anwar Malang \\ ${ }^{3}$ Divisi Gastroenterohepatologi Bagian Ilmu Penyakit Dalam Rumah Sakit Umum Dr. Saiful Anwar Malang
}

\begin{abstract}
ABSTRAK
Obat Anti Inflamasi Non Steroid (OAINS) merupakan obat pilihan utama untuk osteoartritis. Penggunaan OAINS yang kurang tepat dapat menyebabkan gastropati. Penelitian ini bertujuan untuk mengetahui hubungan pola penggunaan OAINS dengan gejala klinis gastropati pada pasien reumatik Penelitian dilakukan dengan desain cross sectional pada 40 orang pasien dipilih dengan metode consecutive sampling. Penelitian ini menilai pola pengguaan OAINS (jenis, lama penggunaan, cara penggunaan, pemakaian obat sitoproteksi ) dan gejala klinis gastropati yang timbul. 55\% pasien mengalami gejala klinis gastropati berupa sindrom dispepsia. Uji Kruskal Wallis gejala klinis gastropati antara penggunaan Na diclofenac, meloxicam, dengan ibuprofen menunjukkan $p=0,732$. Uji regresi logistik lama penggunaan dengan gejala klinis gastropati menunjukkan $p=0,047$. Uji Mann Whitney gejala klinis gastropati pada penggunaan OAINS secara periodik dengan berkelanjutan menunjukkan $\mathrm{p}>0,05$. Uji Mann Whitney gejala klinis gastropati pada penggunaan OAINS bersama obat sitoproteksi dengan penggunaan OAINS tanpa obat sitoproteksi menunjukkan $p=0,000$. Penelitian ini membuktikan bahwa jenis OAINS tidak memberikan perbedaan gejala klinis gastropati, demikian juga penggunaan periodik dan berkelanjutan. Dibuktikan juga bahwa lama penggunaan OAINS berhubungan dengan gejala klinis gastropati dan penggunaan obat sitoproteksi bersama dengan OAINS mengurangi gejala klinis gastropati.
\end{abstract}

Kata Kunci : Gastropati, OAINS, reumatik

\begin{abstract}
Non - Steroidal Anti - Inflammatory Drug (NSAID) is the drug of chice for rheumatic disease. However, NSAID which is used inappropriately will cause gastropathy. This research was conducted to identify the relationship of NSAID application model toward rheumatic patient with gastropathy symptoms in Dr. Saiful Anwar General Hospital Malang. In detail, this research uses cross sectional method. There are 40 patients selected consecutively based on the inclusion and exclusion criteria. Variable being measured were the type of NSAID, the length used of NSAID, the way using NSAID, and the use of cytoprotective drug along with NSAID and the gastropathy symptoms. The result show that there are 55\% patients who have gastropathy in the form of dyspepsia syndrome. The Kruskal Wallis test of gastropathy symptoms between the use of Na diclofenac, meloxicam, and ibuprofen shows show non significant association $(p=0.732)$. The logistic regression show significant influence $(r=0.031, p-0.047)$ of the length used of NSAID with gastropathy symptoms. Mann Whitney test show no significant differences between periodically and gradually consumptions of NSAID. A significant $(p<0.001)$ finding was identified between the use cytoprotective drug and the use of along with NSAIDand gastropathy symptom. It can be concluded that the type of NSAID and its consumption method has no significant association with gastropathy symptom. Consumption duration of NSAID has significant influence in the risk of gastropathy symptom, but the use of cytoprotective agent along with NSAID will reduce the risk.
\end{abstract}

Keywords: Gastropathy, NSAID, rheumatic

Jurnal Kedokteran Brawijaya Vol. 26, No. 2, Agustus 2010; Korespondensi: Yoga Waranugraha. Program Studi Pendidikan Dokter Fakultas Kedokteran Universitas Brawijaya Malang, Jl.Veteran Malang, Tel. (0341) 580993, 567192 Email: yoga_waranugraha_1987@yahoo.com 


\section{PENDAHULUAN}

Penyakit reumatik merupakan penyakit yang banyak diderita oleh masyarakat Indonesia. Jumlah penderita reumatik di Indonesia mencapai 44\% sementara di Asia $26 \%$. Nyeri merupakan keluhan utama yang dialami oleh pasien reumatik. Nyeri pada penyakit reumatik umumnya disebabkan oleh inflamasi. Berbagai usaha dilakukan untuk menghilangkan atau meringankan keluhan ini, antara lain dengan menggunakan medikamentosa. Substansi yang memiliki kemampuan untuk menghambat proses inflamasi dan memiliki efek analgesik serta antipiretik dikiasifikasikan sebagai Obat Anti Inflamasi Non Steroid (OAINS) (1-4).

OAINS dikenal sebagai salah satu faktor agresif eksogen yang dapat menyebabkan kerusakan mukosa lambung, baik secara lokal maupun sistemik. Lesi mukosa lambung tersebut dikenal dengan gastropati. Pasien yang mengalami gastropati dapat mengalami sindrom dispepsia tanpa adanya ulkus, ulkus dengan atau tanpa sindrom dispepsia, atau bahkan komplikasinya yang berupa perdarahan atau perforasi. Di Amerika Serikat, hampir 111.400 .000 resep OAINS dibuat tiap tahunnya dengan harga penjualan senilai 5 miliar dolar Amerika Serikat. Setiap tahun, sekitar 16.500 kematian yang berkaitan dengan OAINS terjadi pada pasien reumatik di Amerika Serikat. Beberapa obat sitoproteksi telah diteliti untuk mencegah terjadinya gastropati (3-8).

Banyaknya jumlah pasien reumatik, insiden gastropati, jumlah kematian yang ditimbulkannya, dan penggunaan OAINS pada terapi penyakit reumatik, mendorong pentingnya kajian penyebab efek samping gastropati pada penggunaan OAINS. Efektifitas pemakaian obat-obat sitoproteksi bersama OAINS untuk mengurangi gastropati juga perlu dibuktikan sebagai dasar dalam manajemen terapi pencegahan gastropati akibat penggunaan OAINS. Penelitian ini dilakukan untuk mengkaji hubungan pola penggunaan OAINS pada pasien reumatik dengan gejala klinis gastropati di RSU Dr. Saiful Anwar Malang (RSSA).

\section{METODE}

Penelitian ini adalah penelitian observasional analitik dengan pendekatan cross sectional di Instalasi Rawat Jalan Reumatologi-Penyakit Dalam RSSA Malang pada bulan Januari sampai dengan Februari 2009.

Populasi target pada penelitian ini adalah masyarakat penderita reumatik yang sedang menjalani terapi OAINS dan memiliki riwayat penggunaan OAINS di di RSSA Malang. Populasi terjangkau dalam penelitian ini adalah pasien reumatik yang sedang menjalani terapi OAINS dan memiliki riwayat penggunaan OAINS yang berobat ke Poli Reumatologi-Penyakit Dalam RSSA selama masa penelitian.

Pengambilan sampel pada penelitian menggunakan metode consecutive sampling pada populasi terjangkau yang bersedia dan memenuhi kriteria. Kriteria eksklusi dalam penelitian ini meliputi: pasien yang pernah menyatakan pernah menderita gastritis atau ulkus peptikum sebelum pasien tersebut menjalani terapi OAINS, mengalami gejala klinis seperti gastropati sebelum pasien tersebut menjalani terapi OAINS, memiliki penyakit saluran pencernaan dan sistemik lain seperti
GERD (Gastroesophageal Reflux Disease), cholelithiasis, gagal ginjal kronis, penyakit paru kronis, cirrhosis, dan lainlain yang memberikan gejala klinis seperti gejala klinis gastropati, dan mengkonsumsi alkohol atau menggunakan obat-obat lain yang memberikan gejala klinis seperti gejala klinis gastropati.

Pola penggunaan OAINS meliputi karakteristik pasien reumatik pengobatan OAINS (jenis kelamin, usia, pekerjaan, pendidikan, dan IMT), OAINS (jenis, dosis, lama, dan cara penggunaan), penggunaan OAINS bersama dengan obat sitoproteksi yang diperoleh dari wawancara dan rekam medik.

Data disajikan secara deskriptif untuk menggambarkan karakteristik pasien reumatik pengonsumsi OAINS (usia, jenis kelamin, pekerjaan, IMT, riwayat merokok, dan konsumsi alkohol), OAINS (jenis, dosis, lama, dan cara penggunaan), penggunaan OAINS bersama dengan obat sitoproteksi, serta gejala klinis gastropati yang timbul (sindrom dispepsia, hematemesis, dan melena). Data dianalisis menggunakan uji Kruskal Wallis, Mann Whitney, serta regresi logistik menggunakan perangkat SPSS 15.0.

\section{HASIL}

Dari 40 orang pasien reumatik yang bersedia menjadi subjek penelitian $25 \%$ adalah laki-laki $42 \%$ dan $75 \%$ persen perempuan. Usia pasien terbanyak adalah sama 60 tahun ke atas. Jika ditinjau dari pekerjaan, yang paling banyak adalah Ibu Rumah Tangga (IRT) sebesar 35\%. Tingkat pendidikan terbanyak adalah SMA sebesar $30 \%$. Sebanyak 47,5\% pasien memiliki IMT yang ideal.

Deskripsi karakteristik responden menunjukkan penyakit osteoarthritis (OA) merupakan penyakit yang paling banyak dijumpai dan paling sering diterapi dengan OAINS. Osteoartritis yang ditemukan sebesar $70 \%$ disusul oleh arthritis reumatiod (AR) sebesar $15 \%$ dan low back pain (LBP) sebesar 5\%. fibromyalgia, gout arthritis, frozen shoulder, dan tendinitis masing-masing sebesar 2,5\%.

Sebagian besar pasien datang dengan keluhan nyeri sedang, sebesar $80 \%$, kemudian diikuti oleh nyeri berat sebesar $12,5 \%$. Pasien yang mengeluh nyeri ringan sebesar $7,5 \%$. Dari 40 pasien yang menjalani terapi dengan OAINS tidak ada yang mengalami gejala klinis gastropati yang berupa hematemesis-melena. Gejala klinis gastropati yang ditemukan hanya sindrom dispepsia. Sebanyak $55 \%$ pasien mengalami sindrom dispepsia dan $45 \%$ pasien tidak mengalami sindrom dispepsia.

Keluhan sindrom dispepsia yang terbanyak adalah nyeri ulu hati (nyeri epigastrium). Keluhan ini dialami 55\% pasien yang mengonsumsi OAINS, diikuti oleh perut terasa penuh, mual, sendawa, sensasi seperti terbakar, dan muntah. Keluhan yang paling jarang dijumpai adalah muntah (10\%).

Dari 40 pasien yang menjalani terapi OAINS, 10 diantaranya memakai obat sitoproteksi yang diminum bersama OAINS. Empat orang menggunakan ranitidin dan 6 orang menggunakan lansoprazole. Semua pasien yang menggunakan sitoproteksi tersebut tidak mengalami gejala klinis gastropati. Pasien yang hanya memakai OAINS tanpa obat sitoproteksi sebanyak 30 orang. Dua puluh tiga orang mengalami gejala klinis gastropati dan 7 orang tidak mengalami (Tabel 1). 
Tabel 1.Tes Kruskal Wallis hubungan penggunaan jenis OAINS dengan gejala klinis gastropati

\begin{tabular}{lcccc}
\hline Jenis OAINS & $\begin{array}{c}\text { Gastropati } \\
(+)\end{array}$ & $\begin{array}{c}\text { Gastropati } \\
(-)\end{array}$ & $\mathrm{N}$ & $\mathrm{p}$ \\
\hline Na diclofenac & 9 & 2 & 11 & \\
Meloxicam & 11 & 5 & 16 & 0,732 \\
lbuprofen & 3 & 0 & 3 & \\
\hline
\end{tabular}

Perbedaan gejala klinis gastropati pada penggunaan jenis OAINS tertentu dianalisis dengan tes Kruskal Wallis. yang menemukan tidak ada perbedaan signifikan $(p=0,732)$. Pengaruh antara lama penggunaan OAINS terhadap gejala klinis gastropati dianalisis dengan regresi logistik yang menunjukkan pengaruh sgnifikan ( $r=0.031 ; p=0,047)$ semakin lama penggunaan OAINS semakin besar resiko timbulnya gejala klinis gastropati.

Perbedaan gejala klinis gastropati pada penggunaan OAINS secara periodik dengan penggunaan OAINS secara berkelanjutan pada kelompok OAINS tertentu dianalisis dengan tes Mann Whitney. Uji menunjukkan tidak ada perbedaan gejala klinis gastropati yang signifikan pada penggunaan OAINS secara periodik dengan penggunaan OAINS secara berkelanjutan (Tabel 2).

Tabel 2. Tes Mann Whitney hubungan cara penggunaan OAINS dengan gejala klinis gastropati

\begin{tabular}{lcccc}
\hline $\begin{array}{c}\text { Cara Penggunaan } \\
\text { OAINS }\end{array}$ & $\begin{array}{c}\text { Gastropati } \\
(+)\end{array}$ & $\begin{array}{c}\text { Gastropati } \\
(+)\end{array}$ & $\mathrm{N}$ & $\mathrm{p}$ \\
\hline $\begin{array}{l}\text { Na diclofenac } \\
\text { periodik }\end{array}$ & 5 & 2 & 7 & \\
$\begin{array}{l}\text { Na diclofenac } \\
\text { berkelanjutan }\end{array}$ & 4 & 0 & 4 & 0,260 \\
$\begin{array}{l}\text { Meloxicam } \\
\text { periodik }\end{array}$ & 7 & 4 & 11 & 0,526 \\
$\begin{array}{l}\text { Meloxicam } \\
\text { berkelanjutan }\end{array}$ & 4 & 1 & 5 & \\
$\begin{array}{l}\text { Ibuprofen } \\
\text { periodik } \\
\text { Ibuprofen } \\
\text { berkelanjutan }\end{array}$ & 1 & 1 & 2 & \\
\hline
\end{tabular}

Perbedaan gejala klinis gastropati pada penggunaan OAINS dengan obat sitoproteksi dengan penggunaan OAINS tanpa obat sitoproteksi dianalisis dengan tes Mann Whitney. Hasil analisis menunjukkan pemberian obat sitoproteksi memberikan perbedaan signifikan $(p=0.000)$ timbulnya gejala klinis gastropati (Tabel 3).

Tabel 3. Tes Mann Whitney hubungan penggunaan obat sitoproteksi dengan gejala klinis gastropati

\begin{tabular}{lcccc}
\hline Penggunaan OAINS & $\begin{array}{c}\text { Gastropati } \\
(+)\end{array}$ & $\begin{array}{c}\text { Gastropati } \\
(-)\end{array}$ & N & p \\
\hline OAINS & 22 & 8 & 30 & \\
$\begin{array}{l}\text { OAINS + } \\
\text { Sitoproteksi }\end{array}$ & 0 & 10 & 10 & 0,000 \\
\hline
\end{tabular}

\section{PEMBAHASAN}

Dalam penelitan ini digunakan 3 jenis OAINS yaitu $\mathrm{Na}$ Diclofenac, Meloxicam, dan Ibuprofen. Dalam penelitian tidak dijumpai penggunaan OAINS inhibitor selektif COX-2 karena mahalnya harga OAINS inhibitor selektif COX-2. OAINS yang paling banyak dipakai adalah Meloxicam karena secara teoritis memiliki efek samping terhadap saluran cerna paling minimal. Literatur menyebutkan bahwa meloxicam mampu menghambat COX-2 sepuluh kali lipat daripada COX-1 pada percobaan ex vivo (9). Karena sebagian besar pasien menderita penyakit kronis dan membutuhkan terapi jangka panjang, sehingga dipilih OAINS yang paling aman yaitu meloxicam dengan harapan insiden gastropati bisa ditekan.

$\mathrm{Na}$ diclofenac sering digunakan karena Na diclofenac bisa berakumulasi dengan baik di cairan synovial setelah pemberian oral. Menurut literatur $\mathrm{Na}$ diclofenac merupakan OAINS yang memiliki durasi efek terapeutik di cairan synovial lebih lama daripada waktu paruh di plasma $(9,10)$. Dalam penelitian ini Na diclofenac banyak dipakai dalam terapi penyakit reumatik karena sebagian besar penyakit reumatik yang dijumpai adalah osteoarthritis. Osteoarthritis merupakan penyakit yang permasalahan nya ada pada kartilago persendian. Sehingga diperlukan obat yang bisa berakumulasi dan bekerja dengan baik di sendi.

Sebagian besar pasien menggunakan OAINS secara periodik. Hal ini karena dokter memberikan informasi yang jelas kepada pasien tentang aturan penggunaan obat. Dengan pengguanaan secara periodik diharapkan insiden gastropati bisa ditekan. Pada sebagian pasien OAINS digunakan bersamaan dengan obat sitoproteksi dengan harapan dapat mencegah munculnya gejala klinis gastropati.

Gejala klinis gastropati yang ditemukan dalam penelitian ini hanya berupa sindrom dispepsia. Tidak ditemukan pasien yang mengalami hematemesis atau melena. Padahal sesungguhnya spektrum klinis gastropati dapat meliputi sindrom dispepsia, ulkus lambung dan duodenum, serta komplikasinya berupa perdarahan $(11,12)$. Hal ini disebabkan karena obat sitoproteksi segera diberikan oleh dokter ketika pasien mengeluhkan keluhan sindrom dispepsia. Dengan demikian diharapkan efek samping OAINS lebih lanjut dapat dicegah.

Dalam penelitian ini sebagian besar pasien yang mengalami gastropati adalah wanita. Hal ini terjadi karena penyakit reumatik lebih sering dialami wanita (1). Osteoarthritis sedikit lebih banyak dijumpai pada wanita dibanding pria sedangkan arthritis reumatoid lebih banyak dijumpai pada wanita. Dalam penelitian ini jenis penyakit reumatik yang paling banyak diderita adalah osteoarthritis (70\%) kemudian disusul oleh arthritis reumatoid (15\%). Akibatnya wanita lebih sering mendapat terapi OAINS yang pada umumnya adalah terapi jangka panjang. Steroid juga sering digunakan dalam terapi arthritis reumatoid. Kombinasi OAINS tradisional dengan kortikosteroid meningkatkan risiko gastropati 2 kali lipat dibandingkan dengan penggunaan OAINS saja (13). Prevalensi penyakit reumatik yang tinggi pada wanita, terapi penyakit reumatik jangka panjang dengan menggunakan OAINS dan penggunaan steroid menyebabkan wanita lebih rentan terhadap gastropati dibandingkan pria.

Pasien yang berusia lebih dari 60 tahun memiliki risiko 5,5 
kali lipat untuk mengalami komplikasi gastrointestinal jika menjalani terapi OAINS (13). Dalam penelitian ini usia pasien yang mengalami gastropati terbanyak adalah usia lebih dari 60 tahun. Hal ini sesuai dengan penelitian sebelumnya dan teori yang ada. Proses penuaan akan menyebabkan efek samping obat lebih dominan daripada efek terapeutik obat. Selain itu, efek toksik obat akan lebih sering muncul.

Menurut literatur $\mathrm{Na}$ diclofenac memberikan efek samping (pada umumnya saluran pencernaan) pada $20 \%$ pasien. Sebanyak $5 \%$ sampai $15 \%$ pasien mengalami efek samping gastrointestinal setelah pemberian ibuprofen (9). Meloxicam menunjukkan penghambatan COX-2 sepuluh kali lipat daripada COX-1 pada percobaan ex vivo (9). Pernyataan di atas menunjukkan jika masing-masing jenis OAINS memiliki kemampuan yang berbeda-beda untuk menimbulkan efek samping pada saluran pencernaan.

Penelitian ini mengidentifikasi penggunaan 3 jenis OAINS yaitu Na diclofenac, meloxicam, dan ibuprofen. Dosis yang digunakan adalah $\mathrm{Na}$ diclofenac $50 \mathrm{mg}$ dua kali sehari, meloxicam $15 \mathrm{mg}$ satu kali sehari, dan ibuprofen $400 \mathrm{mg}$ tiga kali sehari. Dosis tersebut adalah dosis ekuivalen, di mana Na diclofenac 50 mg dua kali sehari setara dengan meloxicam $15 \mathrm{mg}$ satu kali sehari setara dengan ibuprofen $400 \mathrm{mg}$ tiga kali sehari (14). Dosis tersebut merupakan dosis terapi yang dianjurkan.

Hasil menunjukkan tidak terdapat perbedaan gejala klinis gastropati yang signifikan pada penggunaan $\mathrm{Na}$ diclofenac, meloxicam, dan ibuprofen. Hasil tersebut bertentangan dengan pernyataan sebelumnya yang mengatakan bahwa masing-masing OAINS memiliki kemampuan yang berbeda dalam menimbulkan efek samping pada saluran pencernaan. Hal tersebut terjadi karena dalam kurun waktu 1 tahun terakhir seorang pasien bisa saja menjalani terapi dengan OAINS yang berbeda jenis. Gastropati yang muncul bisa saja bukan efek dari satu jenis OAINS saja. Akibatnya sulit untuk menentukan bahwa gejala klinis gastropati yang muncul apakah benar-benar murni efek samping dari salah satu jenis OAINS.

Setelah meminum OAINS, kerusakan epitel permukaan lambung terjadi dalam beberapa menit. Perdarahan dan erosi epitel gastroduonenum dapat terjadi dalam beberapa jam (15). Pernyataan tersebut hanya bisa dibuktikan jika mukosa lambung dilihat secara langsung. Dengan adanya pernyataan seperti di atas dimungkinkan untuk muncul gejala klinis gastropati secara cepat mengingat kerusakan dan iritasi topikal mukosa lambung dapat terjadi dalam waktu yang singkat.

Data penelitian menunjukkan bahwa pasien menjalani terapi mulai dari 15 hari sampai 120 hari dalam satu tahun terakhir ini. Data ini diperoleh dari jumlah obat yang diresepkan dokter kepada pasien dan lama terapi yang direncanakan oleh dokter yang tertulis dalam rekam medik. Data ini diambil karena semua pasien tidak tahu berapa jumlah pasti OAINS yang telah mereka minum dalam kurun waktu satu tahun terakhir ini.

Pengaruh lama penggunaan OAINS terhadap gejala klinis gastropati dianalisis dengan regresi berganda binary dengan menggunakan logistik. Didapatkan hasil ada pengaruh antara lama penggunaan OAINS terhadap gejala klinis gastropati. Hasil ini sesuai dengan pendapat sebelumnya yang mengatakan bahwa penggunaan OAINS yang berkepanjangan merupakan salah satu faktor risiko terjadinya gastropati walaupun masih kontroversi (13). Pengaruh lama penggunaan OAINS terhadap gejala klinis gastropati adalah pengaruh positif sebesar 0,031 artinya setiap perubahan 1 hari lama terapi dengan menggunakan OAINS, kemungkinan pasien untuk mengalami gastropati meningkat sebesar 3,10\%.

Penggunaan OAINS jangka panjang menyebabkan penghambatan COX-1 yang berfungsi secara fisiologis dalam waktu yang lama. Dampak dari penghambatan COX1 tersebut adalah berkurangnya sintesis prostaglandin fisiologis sehingga regenerasi mukosa lambung menjadi terhambat. Selain itu, penggunaan OAINS jangka panjang menyebabkan iritasi lokal mukosa lambung menjadi lebih lama dan lebih hebat. Sehingga mukosa lambung yang semula masih baik dapat mengalami kerusakan atau mukosa lambung yang sudah rusak dapat menjadi semakin rusak.

Gastropati yang muncul dapat dinilai dari klinis maupun gambaran mukosanya. Gejala klinis yang muncul dapat berupa sindrom dispepsia, hematemesis, dan melena. Dalam penelitian ini hanya dinilai gejala klinis gastropati sedangkan gambaran mukosa lambung tidak dinilai. Semakin lama pasien mengonsumsi OAINS semakin besar risiko untuk mengalami gejala klinis gastropati.

Dari 30 orang pasien yang menggunakan OAINS tanpa menggunakan obat sitoproteksi, 19 orang menggunakan OAINS secara periodik dan hasil menyebutkan terdapat perbedaan gejala klinis gastropati yang signifikan pada penggunaan OAINS secara periodik dengan penggunaan OAINS secara berkelanjutan

Penggunaan OAINS secara periodik memberikan peluang mukosa lambung untuk mengalami regenerasi lebih besar daripada penggunaan OAINS secara berkelanjutan. Hal ini terjadi karena pada penggunaan OAINS secara periodik ada waktu jeda di mana sintesis prostaglandin fisiologis tidak dihambat. Akan terjadi regenerasi atau perbaikan mukosa lambung karena adanya peningkatan sekresi mukus, sekresi bikarbonat, aliran darah ke mukosa, ploriferasi sel epitel. Ketahanan mukosa terhadap asam lambung, pepsin, dan empedu juga akan meningkat. Pada penggunaan OAINS secara periodik, iritasi lokal mukosa lambung juga terjadi tidak secara terus-menerus. Dengan pemikiran seperti ini seharusnya pasien yang meggunakan OAINS secara periodik memiliki peluang mengalami gejala klinis gastropati yang lebih kecil daripada pasien yang menggunakan OAINS secara periodik.

Hasil penelitian menunjukkan tidak terdapat perbedaan gejala klinis gastropati yang signifikan pada penggunaan OAINS secara periodik dengan penggunaan OAINS secara berkelanjutan. Hal ini terjadi karena dalam kurun waktu 1 tahun terakhir seorang pasien bisa saja menjalani terapi dengan OAINS yang berbeda jenis dengan cara yang berbeda pula. Sehingga sulit untuk menentukan bahwa gejala klinis gastropati yang muncul apakah benar-benar murni pengaruh cara penggunaan OAINS saja.

Ketahanan dan kemampuan regenerasi mukosa lambung masing-masing individu juga berbeda-beda. Jeda waktu di mana pasien tidak mengonsumsi OAINS yang ada pada penggunaan OAINS secara periodik belum tentu menyebabkan perbaikan kerusakan mukosa secara sempurna, sehingga risiko timbulnya gejala klinis gastropati pada penggunaan OAINS berikutnya masih ada. 
Pasien yang mendapat terapi OAINS bersama dengan obat sitoproteksi tidak ada yang mengalami gejala klinis gastropati. Obat sitoproteksi yang banyak digunakan adalah lansoprazole kemudian ranitidine. Lansoprazole yang merupakan obat golongan PPI (Proton Pump Inhibitor) yang direkomendasikan oleh FDA (Food and Drug Administration) untuk terapi dan pencegahan ulkus lambung akibat penggunaan OAINS (gastropati) yang berulang pada pasien yang mejalani terapi OAINS jangka panjang. Obat ini bekerja dengan cara mengambat $\mathrm{H}^{+} \mathrm{K}^{+}$ATPase secara ireversibel (16). Lansoprazole dipilih karena obat ini secara potensial menghambat semua fase sekresi asam lambung. Dengan dosis harian yang berulang, akan terjadi efek penghambatan sekresi asam secara progresif (17).

Antagonis reseptor $\mathrm{H}_{2}$ menghambat sekresi asam lambung dengan cara kompetisi dengan histamin untuk berikatan dengan reseptor $\mathrm{H}_{2}$ yang berada di membran basolateral sel parietal. Ikatan tersebut merupakan ikatan yang reversibel. Saat ini tersedia empat jenis obat dari golongan ini yaitu simetidin, ranitidine, famotidine, dan nizatidine (17). Dalam penelitian ini obat golongan antagonis reseptor $\mathrm{H}_{2}$ yang dipakai adalah ranitidin. Ranitidin dipilih karena relatif lebih aman daripada simetidin.

Efek samping simetidin berupa efek antiandrogenik lemah yang dapat menyebabkan ginekomastia dan impotensi pada pria. Efek yang lebih penting adalah efek semping simetidin yang berupa penghambatan enzim sitokrom P450 (17). Penghambatan enzim ini berakibat menurunnya metabolisme obat di hati. Sebagian besar pasien reumatik berusia lanjut. Bertambahnya usia menyebabkan menurunnya fungsi organ terutama hati dan ginjal yang memiliki peranan penting dalam metabolisme dan ekskresi obat. Pasien usia lanjut juga sering menjalani pengobatan berbagai penyakit dan mengonsumsi beberapa jenis obat. Sehingga pemberian simetidin pada pasien usia lanjut tidak dianjurkan, karena berisiko meningkatkan terjadinya keracunan obat. Terutama yang dimetabolisme dan diekskresi oleh hati. Hal inilah yang mendasari pemakaian ranitidine lebih dianjurkan daripada penggunaan simetidin.

\section{DAFTAR PUSTAKA}

1. Isbagio H. Strategi Pengobatan Medikamentosa Penyakit Reumatik. Cermin Dunia Kedokteran. 1992; 78: 25-31.

2. Lelo A, Hidayat DS, dan Juli S. Penggunaan AntiInflamasi Non Steroidyang Rasional pada Penanggulangan Nyeri Rematik. [Repositori]. Universitas Sumatera Utara, Medan. 2004

3. Steinmeyer J. Pharmacological Basis for The Therapy of Pain and Inflammation with Nonsteroidal AntiInflammatory Drugs. Arthritis Research. 2000; 2(5): 379-385.

4. Saleh R. Ketergantungan Obat Penderita Radang Sendi. (Online) 2006. www.monitordepok.com [Diakses tanggal 25 November 2007].

5. Davies NM and Wallave JL. Nonsteoridal AntiInflammatory Drug-induced Gastrintestinal Toxicity: New Insights Into an Old Problem. Journal of Gastroenterology. 1997; 32: 127-133.
Terdapat perbedaan gejala klinis gastropati yang signifikan pada penggunaan OAINS bersama obat sitoproteksi dengan penggunaan OAINS tanpa obat sitoproteksi. Hal ini karena pada penggunaan OAINS bersama obat sitoproteksi, selain diberikan agen yang memiliki kemampuan untuk merusak mukosa lambung, juga diberikan agen yang mampu mempertahankan atau memperbaiki integritas mukosa lambung dari kerusakan. Dengan strategi terapi seperti ini diharapkan kerusakan mukosa lambung bisa dicegah, dikurangi, atau dihilangkan sehingga tidak muncul gejala klinis gastropati.

Gastropati terjadi melalui dua mekanisme yaitu mekanisme lokal dan sistemik. Mekanisme sistemik terjadi melalui penghambatan sintesis prostaglandin, sedangkan mekanisme lokal merupakan akibat dari gangguan topikal oleh OAINS. Gangguan topikal ini mengakibatkan serangkaian perubahan permukaan mukosa, menyebabkan ion $\mathrm{H}^{+}$dan pepsin merusak sel epitel lebih lanjut $(13,15,17)$. Dalam penelitian ini digunakan obat sitoproteksi golongan PPI dan antagonis reseptor $\mathrm{H}_{2}$. Keduanya memiliki efek terapi berupa penghambatan pengeluaran asam lambung. Dengan dihambatnya pengeluaran asam lambung, maka kadar bahan perusak yang ada di lumen berkurang jumlahnya dan gangguan topikal pada lambung bisa dikurangi. Sayangnya PPI dan antagonis reseptor $\mathrm{H}_{2}$ tidak berpengaruh terhadap mekanisme sistemik karena kedua golongan obat tersebut tidak bekerja pada proses pembentukan atau penghambatan prostaglandin. Meskipun ketahanan mukosa lambung menurun akibat penurunan kadar prostaglandin, keutuhan mukosa lambung masih bisa dijaga atau dipertahankan dengan cara mengurangi bahan-bahan perusak mukosa lambung yaitu dengan menggunakan PPI dan antagonis reseptor $\mathrm{H}_{2}$.

Dari penelitian ini terbukti bahwa lama pemberian OAINS berhubungan dengan gejala klinis gastropati, sedangkan jenis dan pemberian periodik atau berkelanjutan tidak menunjukkan. Pemberian obat sitoproteksi bersama dengan OAINS akan mengurangi gejala klinis gastropati Studi lanjut dengan pemeriksaan endoskopi perlu dilakukan untuk memastikan efek pemberian OAINS dan obat sitoproteksi pada mukosa lambung.

6. Nasution AR. Obat Anti Inflamasi Non Steroid sebagai Penyebab Terbanyak Pendarahan Saluran Cerna Bagian Atas. Majalah Kedokteran Bandung. 2003; 35(1).

7. Wongso S, Manaf A, dan Julius. Proteksi Mukosa Lambung terhadap Obat-obat Antiinflamasi Nonsteroid. Cermin Dunia Kedokteran. 1992; 79: 2225.

8. Bystrianyk R. Toxic and Deadly NSAIDS: An Investigation Report. (Online) 2002 www. healthsntinel.com/printer. php?id=144 [diakses tanggal 3 Oktober 2007]

9. Burke A, Smyth E, and FitzGerald GA. AnalgesicAntipyretic Agent, Pharmacotherapy of Gout S. In: Brunton LL, Lazo JS, and Parker KL. Goodman and Gillman's the Pharmacological Basis of Therapeutics 11th edition. USA: The McGraw-Hill Companies; 2006.

10. Wagner W, Khanna P, and Furst D. Nonsteroidal 
Antiinflamatory Drugs, Disease Modifying Antirheumatic Drugs, Nonopioid Analgesics, and Drugs Uses in Gout. In: Katzung BG. Basic \& Clinical Pharmacology 9th edition. San Francisco, USA: The McGraw-Hill Companies; 2004; p. 576-603.

11. Rodríguez LAG' and Díaz SH. Risk of Uncomplicated Peptic Ulcer among Users of Aspirin and Nonaspirin Nonsteroidal Antiinflammatory Drugs. American Journal of Epidemioogy. 2004; 159: 23-31.

12. McQuaid KR. Disease of Stomach and Duodenum. In: McPhee SJ, Papadakis MA, and Tierney LM. Current Medical Diagnosis and Treatment 2008 47th edition. San Francisco, USA: The McGraw-Hill Companies; 2008; p. 514-528.

13. Fugit RV and Fendrick AM. The Role of Gastro protection in Patients on NSAID Therapy. (Online) 2006. http://www.pharmacytimes.com/ issues/articles/2006-7_3698.asp [diakses tanggal 11 Desember 2007].
14. Rabow MW and Pantilat SZ. Palliative Care and Pain Management. In: McPhee SJ, Papadakis MA, and Tierney LM. Current Medical Diagnosis and Treatment 2008 47thedition. San Francisco, USA: The McGraw-Hill Companies; 2008; p. 67-76.

15. Wolfe MM, David R, Lichtenstein DR, and Singh G. Gastrointestinal Toxicity of Nonsteroidal Antiinflamatory Drugs. The New England Journal of Medicine. 1999; 24(340): 1888-1899.

16. Hoogerwerf WA and Pasricha PJ. Pharmacotherapy of Gastric Acidity, Peptic Ulcers, and Gstro Esophageal Reflux Disease. In: Brunton LL, Lazo JS, and Parker KL. Goodman and Gillman's The Pharmacological Basis of Therapeutics 11th edition. USA: The McGraw-Hill Companies; 2006.

17. Valle JD. Peptic Ulcer Disease and Related Disorders. In: Kasper DL, Fauci AS, Longo DL, Braunwald E, Hauser SL, dan Jameson JL. Harrison's Principles of Internal Medicine 16th edition. San Francisco, USA: The McGraw-Hill Companies; 2005; p. 1746-1763. 